\title{
STRUCTURAL CHANGES IN RUSSIA'S INDUSTRY: THE CURRENT SITUATION AND FORECAST
}

\section{Yuri Belkin}

Plekhanov Russian University of Economics, Department of Commodity Science and Commodity Expertise, Moscow, Russian Federation

\section{Alla Ryzhakova}

Plekhanov Russian University of Economics, Department of Commodity Science and Commodity Expertise, Moscow, Russian Federation

\section{Nadezhda Sedova}

Plekhanov Russian University of Economics, Department of National and Regional Economics, Moscow, Russian Federation

\section{Anatoly Shishkin}

Plekhanov Russian University of Economics, Educational Scientific Center "Trade", Moscow, Russian Federation

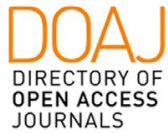

\section{Cite article:}

Belkin, Y., Ryzhakova, A., Sedova, N., Shishkin, A. (2021) STRUCTURAL CHANGES IN RUSSIA'S INDUSTRY: THE CURRENT SITUATION AND FORECAST, Journal of Applied Engineering Science, 19(3) 649-658, DOI:10.5937/jaes0-29159 


\title{
STRUCTURAL CHANGES IN RUSSIA'S INDUSTRY: THE CURRENT SITUATION AND FORECAST
}

\author{
Yuri Belkin 1 , Alla Ryzhakova', Nadezhda Sedova ${ }^{2 *}$, Anatoly Shishkin ${ }^{3}$ \\ ${ }^{1}$ Plekhanov Russian University of Economics, Department of Commodity Science and Commodity \\ Expertise, Moscow, Russian Federation \\ 2Plekhanov Russian University of Economics, Department of National and Regional Economics, Moscow, \\ Russian Federation \\ ${ }^{3}$ Plekhanov Russian University of Economics, Educational Scientific Center "Trade", Moscow, Russian \\ Federation
}

Purpose: The objective of this paper is to analyze the dynamics of change in industrial production in Russia from 2008 to 2019 across a set of indicators characterizing structural changes in industry, specifically its extractive, manufacturing, and production and distribution of electricity, gas, and water sectors. Design/Methodology/Approach: The work provides a forecast of output in the three sectors of industry using methods such as Holt's method and factor analysis, with structural shifts projected using the methods of Szalai, Ryabtsev, Gatev, and Kazinets.

Findings: The empirical results show further changes in the structure of industrial production in the Russian Federation and an increase in manufacturing production at the same time due to a decrease in production by the type of activity "Mining".

Practical Implications: Investors who plan to invest in the Russian Federation should bear in mind that investments in manufacturing production are advisable.

Originality/value: To initiate progressive structural changes, the development and qualitative transformation of the structure of the manufacturing industry is necessary.

Key words: industry, structural changes, forecasting, COVID-19

\section{INTRODUCTION}

Humanity's massive leaps in technological development and innovation have provided an impetus for the development of the process of globalization, which, in turn, has led to the formation of a competitive global environment, giving rise to and stimulating the development of processes of integration. Furthermore, amid the latest geopolitical and monetary-financial changes, the current state of the international financial-economic system is such that there are emerging various external conditions that are influencing the economic system of just about any nation around the world. There, therefore, appears to be a need for adequate and efficient mechanisms for the development and protection of the national economy.

Russia's transition from an administrative-command economy to a market one has been characterized by the use of a special model of development - the resource-based model. The use of the resource-based model of development has been fraught with the structure of the economy becoming more primitive and the role of technology, science, and education diminishing. As a result, the country has witnessed strong differentiation between its regions and a lagging-behind of the sectors of its industry, as well as its technological and innovation sectors, which has made the Russian market highly dependent on foreign products, including technology. On top of that, the Russian economy has been faced with a number of long-term systemic challenges grounded in both the latest global trends and various domestic barriers to development. These challenges include stiffening global competition, a new wave of technological changes, and the exhausted potential of the resource-export model.

At the same time, the organizational structure of Russian industry has been characterized by a high degree of concentration and centralization of capital in the sectors of the fuel-and-energy complex and a highly unequal distribution of capital across the sectors of the manufacturing industry, which, consequently, have found themselves unable to compete in global markets.

In this regard, the conduct of systematic analysis of industry's sectoral structure for the purpose of helping enhance it may be viewed as a key condition for boosting the efficiency of social production and, consequently, driving growth in the national economy.

\section{LITERATURE REVIEW}

Modern structural concepts view structural changes in industry not as a consequence but as a source of economic growth (Lin, 2011). Overall, research has identified a positive correlation between the intensity of structural shifts and the rate of economic growth for 108 nations in the period 1995-2011 (UNIDO, 2016). With that said, this relationship is not absolute, and the intensity of structural changes can be both a consequence and a 
cause of economic growth. Nevertheless, it is worth noting that all significant and long periods of fast economic growth following World War II normally occurred against a backdrop of pronounced structural changes within the national economy (e.g., industrialization or sometimes servicization of the economy, like in Hong Kong or India) (McMillan et al., 2017; Diao, 2017). According to scholar J.J. Krüger, "to date there exists no general theory of structural change, but there exist a variety of theoretical approaches that are concerned with the explanation of structural shifts between the three broad sectors of the private economy [primary, secondary, and tertiary] and among the industries within these sectors" (Krüger, 2008, p. 331). A key concept that belongs here is the three-sector hypothesis, which postulates a systematic succession of the development of the three main sectors of the private economy (Clark, 1957; Fisher, 1939; Fourastie, 1963). Of relevance also are related summarizations by $\mathrm{S}$. Kuznets, who suggests that "rapid changes in production structure are inevitable - given the differential impact of technological innovations on the several production sectors, the differing income elasticity of domestic demand for various consumer goods, and the changing comparative advantage in foreign trade" (Kuznets, 1973, p. 250).

While identifying steady trends in structural change across the global economy is important in and of itself, it is, above all, of particular significance to the development of structural policy in Russia. One is currently observing the following two major types of structural change in the economy - intersectoral structural shifts and intrasectoral ones, which lead to a change of specialization and result in production diversification. The manufacturing industry remains a key driver of economic growth due to the following: high absolute levels of labor productivity; possibility of achieving significant economies of scale; high levels of innovation; well-developed direct and inverse intersectoral relationships; ease of integrating into global production systems (which helps ensure the transfer and absorption of cutting-edge technology) (Abbas, 2018); positive effect on sociality (in particular, in terms of combating income inequality); eco-friendliness of production (Szirmai, 2012). A well-developed manufacturing sector helps maintain overall economic growth thanks to making its stretches longer and reducing overall volatility (UNIDO, 2016; Dasgupta and Singh, 2006). In addition, empirical data suggest the significance of the sectoral composition of exports and the level of their complexity to stimulating overall economic growth (Hidalgo et al., 2011), which accentuates the importance of having in place a well-developed manufacturing industry and a sound services sector complementing it to provide for that complexity.

In this regard, of special significance are structural changes in the industrial sector (Timmer, M, 2009) which is crucial to the development of any country and is an essential sector of material production. Industrial production also serves as a basis for the industrialization of economic space. The essence of industrial production is activity by enterprises and organizations engaged in the extraction and processing of raw materials, fabrication of materials and equipment, and manufacture of instruments of labor. The sector is called industrial or secondary, as it is within this particular sector that primary raw materials are transformed into products ready for consumption by the end user.

Russia's industrial production continues to be in the post-industrial era the basis of the nation's economic security and the kernel of its production-technological potential, expanding and upgrading which constitutes the material-technical part of the reproduction process.

\section{METHODS}

The key indicators of the structure of the national economy reflecting the depth and complexity of changes in production and in the spheres of distribution and consumption are macroeconomic indicators and their dynamics. Establishing a methodology that will factor in the dynamics of such changes in the economic structure is of utmost significance to the study of structural shifts in industry. The classic approach is based on data for the time series of a particular indicator and structural differences based on data for several indicators at a fixed point in time.

To conduct generalized analysis of change in the structure of a set over time or to measure spatial differences based on two compared levels, various summarizing indicators of structural change can be employed. To determine the degree of influence of factor changes on structural transformations, the index method can be employed. A major role in the development of a system of interrelated indexes suitable for this type of analysis has been played by the following statisticians: K. Gatev, L.S. Kazinets, V.M. Ryabstev, and A. Szalai.

Indicators of the effectiveness of structural shifts are often at variance with overall indicators of the economy's development. For instance, effective changes aimed at the structural reformation and diversification of the economy are often accompanied by declines in key macroeconomic indicators of its performance, as they divert toward themselves a portion of existing resources. At the same time, not always do structural shifts that facilitate high rates of economic growth are positive from a standpoint of the direction of socio-economic progress. This happens when growth is achieved through an increased share in the structure of the economy of obsolescent, as well as traditional, sectors (e.g., the share of the extractive industry at the post-industrial economic development stage).

From the perspective of marginal utility theory, a structural shift in the economy is effective only when it leads to its subjects, whose needs are to be met and interests are to be accommodated, deriving maximum utility from the dynamically changing structure of the economic system. Here the primary focus is on the qualitative and quantita- 


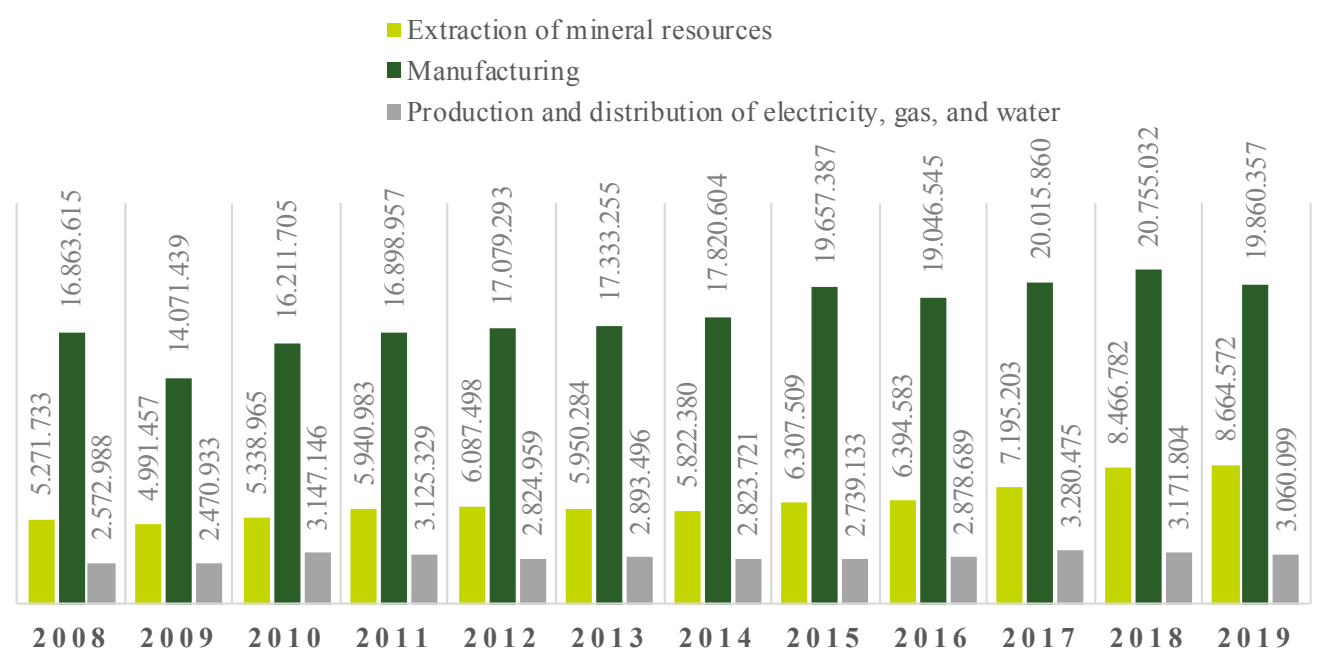

Figure 1: Dynamics of the volume of industrial production in Russia across the three key types of activity, million rubles

tive parameters of structural change in the economy (Cadot O., 2007). Thus, there is a need for a set of indicators that will reflect key structural changes.

Kazinets's linear coefficient of absolute structural changes makes it possible to assess the intensity of structural differences in absolute terms. Gatev's integral coefficient (the Gatev index) helps assess the intensity of structural differences in relative terms. So does the Szalai index. The Ryabtsev index is the ratio of the actual differences between the values of the components of two structures to their maximum possible values.

To forecast structural changes in Russia's industrial sector for the period 2020-2022, the authors employed Holt's method (a two-parameter model was constructed) and factor forecasting.

\section{RESULTS}

Forecasting structural changes in the industrial sector of the Russian economy requires the use of a set of metrics based on which to draw a conclusion about the development level of Russia's industry. Employing these metrics can help establish a relationship between the system's various indicators and determine the degree of correlation between them.

The 2007 All-Russian Classifier of the Types of Economic Activity subsumes the following three types of activity under industrial production:

- extraction of mineral resources;

- manufacturing;

- production and distribution of electricity, gas, and water.

To forecast structural changes in the industrial sector of the Russian economy, one will need three systems of indicators reflecting a set of general and specific factors in the development of each of the types of activity. To this end, the following set of indicators was selected:

- main indicators: volume of shipped goods and performed works and services in value terms;

- general indicators: investment in fixed assets, export growth rate, wear and tear on plant and equipment, and average annual number of employed persons in the sector;

- specialized indicators: oil prices, capital outflow, share of workers with a higher education, invention activity coefficient, population size, demand for electricity, and emissions to the atmosphere.

Due to the paper's limited scope, it will focus on the indicators that the authors feel have a decisive influence in terms of structural shifts.

The Volume of Shipped Goods and Performed Works and Services indicator is a general indicator that characterizes the overall condition and development level of Russia's industry. It can help compute the indices of structural change and generate a forecast for the development of the nation's industrial complex in the future. Figure 1 illustrates the dynamics of the volume of industrial production in Russia.

Good macroeconomic conditions in Russia, a sound budgetary policy, and being immune to the effects of the US mortgage-lending crisis have partially protected the Russian economy and limited the impact on it of the global financial crisis of 2008-2010. Thanks to Russia's small foreign national debt, double budget surplus, substantial gold and currency reserves, and favorable ratings from major rating agencies, up until mid-2008 foreign investors regarded Russia to be a country that is safe and protected from the worsening of financial conditions around the world. If by the start of the global financial crisis Russia had not had such a large budget surplus and such a large volume of resources amassed in the stabilization fund and gold and currency reserves, the crisis would have taken its toll on the Russian economy a lot earlier and its consequences could have been a lot more serious. Starting in 2009 , the manufacturing industry exhibited a steady trend of increase in output, with the positive dynamics persisting up until 2015 . The largest increase in the figure was posted in the period 2014-2015-1,770,461.05 million rubles (10\%). This 


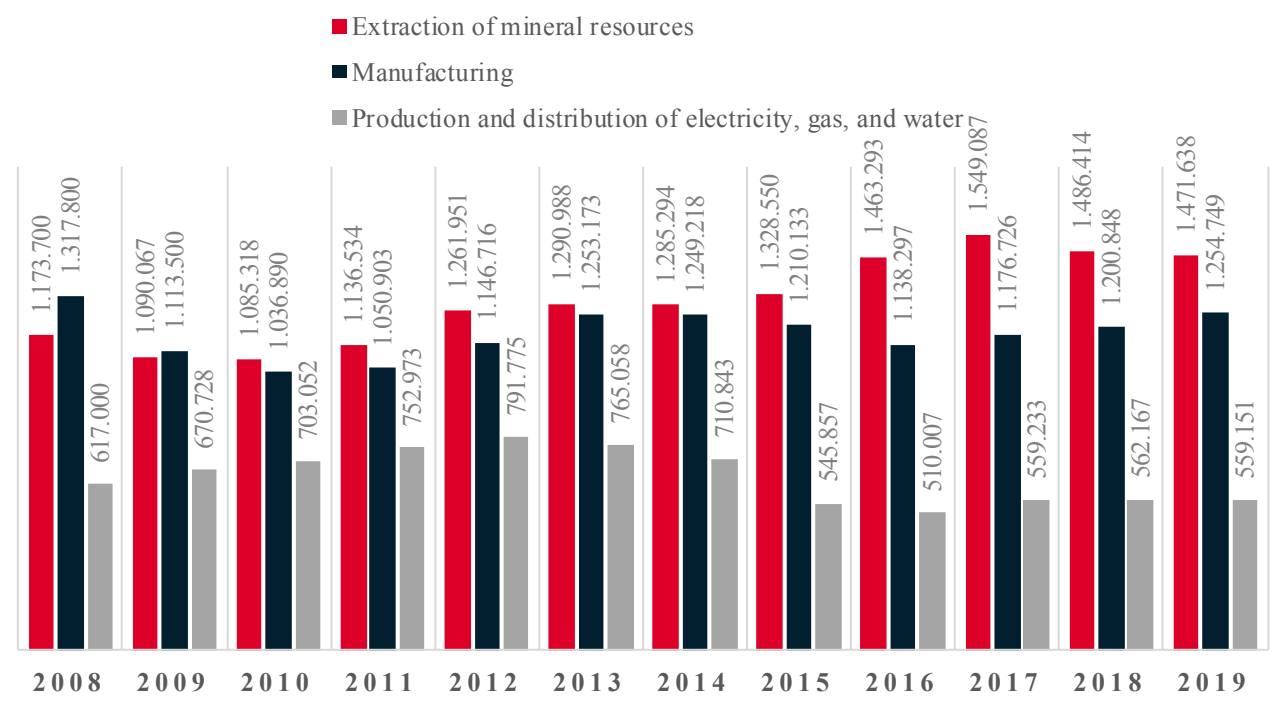

Figure 2: Dynamics of investment in fixed assets across the three key sectors of Russia's industry, million rubles

growth was based on the output of certain food products (including under the import-substitution program), a boost in output in the nation's light and electro-technical industries, and an increase in the output of products from oil and gas processing.

Despite the resource orientation of the Russian economy, the nation did not witness a substantial increase in output in the extractive sector up until 2017, when it posted an increase of $797,800.37$ million rubles $(13 \%)$. Starting in 2015, positive dynamics within the sector were exhibited by enterprises engaged in the extraction of coal, oil, iron ore, and associated gas, whereas there was a decline in the output of natural gas and aggregates. In 2018, output in the extractive sector exceeded the 2014 figure by $9.5 \%$. That being said, even in 2015 , a recessionary year in Russia, the figure remained positive.

Based on data from Rosstat, in 2019 the key factors hindering growth in output in the extraction of mineral resources and manufacturing sectors were insufficient demand for the companies' products in the domestic market, high taxes, and an uncertain economic situation overall.

The development of any sphere of the economy is directly dependent on the level of investment activity within it. The Investment in Fixed Assets indicator reflects the degree to which entrepreneurs are interested in the development of various spheres of economic activity. Investment in fixed assets is also an efficient tool for altering the existing structure of industrial production. Figure 2 illustrates the dynamics of investment in fixed assets across the three key sectors of Russia's industry.

In terms of investment in fixed assets, subsequent to the crisis of 2008-2010 the nation's extractive sector went through a period of rehabilitative growth up until 2017 . A key aspect of the recovery in the investment climate was a change in the structure of sources of investment. The share of their own funds in the total volume of investment in fixed assets among the sector's large and medium-sized enterprises was over $50 \%$.
The largest share of investment in fixed assets was posted in the period under review by the Extraction of Mineral Resources type of activity. This trend reflects (Araujo, R., 2007; Kruger J.J., 2008) the significant investment attractiveness of the resources sector even in today's climate of relatively low global energy prices.

The dynamics of investment in fixed assets in the manufacturing sector are characterized in the period under review by having a cyclical nature. The period 2008-2010, a time of crisis, witnessed a decline in investment in the sector. The figure rose in the period 2011-2013. It then dropped through to 2016. Starting in 2016, while there has been a slowdown in growth in investment, the trend has been one of a general increase.

The rate of growth in exports is another key indicator of the development of Russia's industry. The basis of Russian exports is made up of the Extraction of Mineral Resources type of activity, specifically fuel-and-energy products. In 2019, the relative share of these products in the commodity structure of the nation's exports was $64.7 \%$. At the same time, the share of output from the Manufacturing type of activity in the structure of Russia's exports remains low to this day. This factor is generating additional risk for the economy amid unstable global raw materials prices.

Wear and tear on plant and equipment is a factor that has had a negative effect on the development of the Russian economy. In Russia, organizations that are lagging behind technologically tend to depend on government support to be financially viable. Today, the active portion of plant and equipment appears to be subject to faster physical (and, especially, moral) wear and tear due to scientific-technical progress. Timely upgrades to plant and equipment will have a direct effect on a company's innovativeness, facilitating boosts in its efficiency and competitiveness. Figure 3 illustrates the dynamics of wear and tear on plant and equipment in Russia.

The key reasons behind the high level of wear and tear 


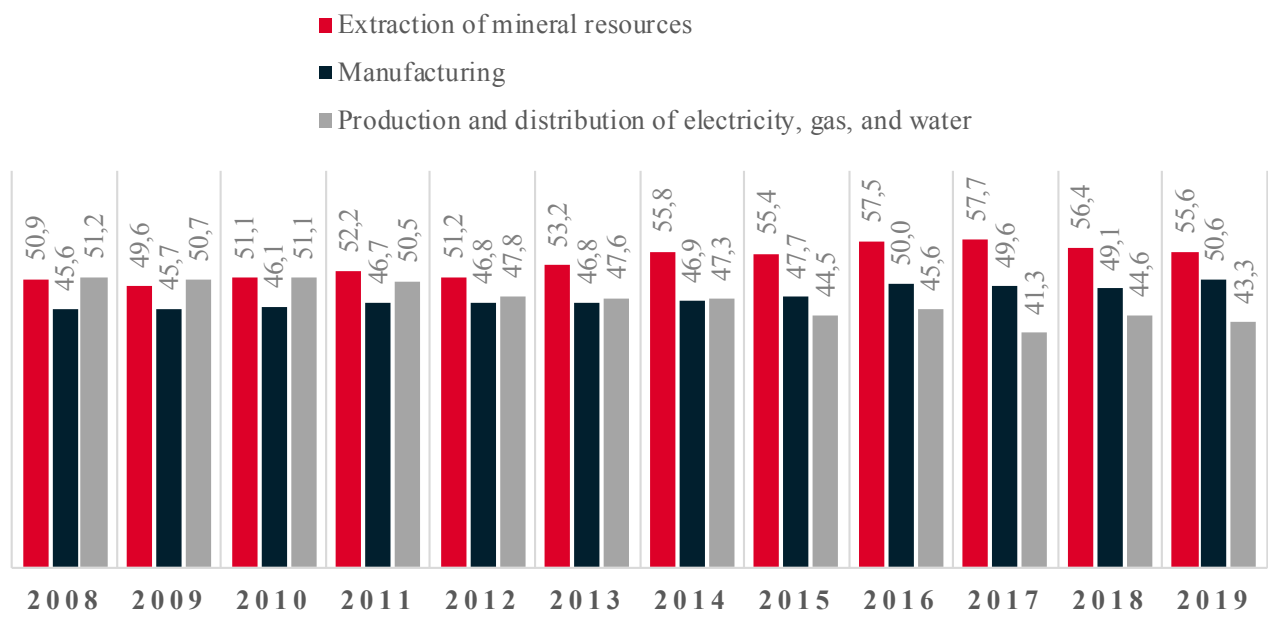

Figure 3: Dynamics of wear and tear on plant and equipment across the sectors of industry, \%

on plant and equipment in Russia are the following: shortage of a skilled workforce, tendency to economize on the development of an enterprise, and lack of proper control over the use of plant and equipment. Many companies hire blue- and white-collar employees who do not have the necessary qualifications to do the job, which then leads to multiple violations. Most companies seek to derive profit in the short term, with little regard for their long-term prospects. Consequently, plant and equipment tends to be upgraded very rarely (McMillan, 2014), which leads to gradual moral wear and tear to the machines and, based on that, to a decline in the company's competitiveness - and may even lead to its being pushed out of the market.

The period under review, 2008-2019, witnessed an increase in said figure in the extraction of mineral resources and manufacturing sectors. At the same time, the production and distribution of electricity, gas, and water sector exhibited an opposite trend. The positive dynamics were associated with the emergence of new solutions in the areas of technology, transportation, and distribution of electricity, gas, and water.

The average annual number of employed persons in the sector, as a social factor in the development of industry, reflects the scale of production. The creation of new jobs is closely associated with the expansion of production, building of new plants, and introduction of new types of products. Figure 4 illustrates the dynamics of Russia's average annual number of employed persons in industry. The Extraction of Mineral Resources and Production and Distribution of Electricity, Gas, and Water types of activity exhibited an increase in number of employed persons throughout the timeframe. Extraction of mineral resources is one of the highest paying sectors in Russia's industry, so staffing is not a major issue in this field. The relatively stable number of employed persons in the production and distribution of electricity, gas, and water sector is associated with the fact that the number of staff employed by enterprises in this sector is sufficient and the high level of pay offered in it, which in the period under review was at the level of $114.2 \%$ relative to the average pay across the Russian economy, has helped preserve its workforce. The structure of employment in the manufacturing sector was characterized by a dynamic decline in employment in the machine-building and consumer complexes.

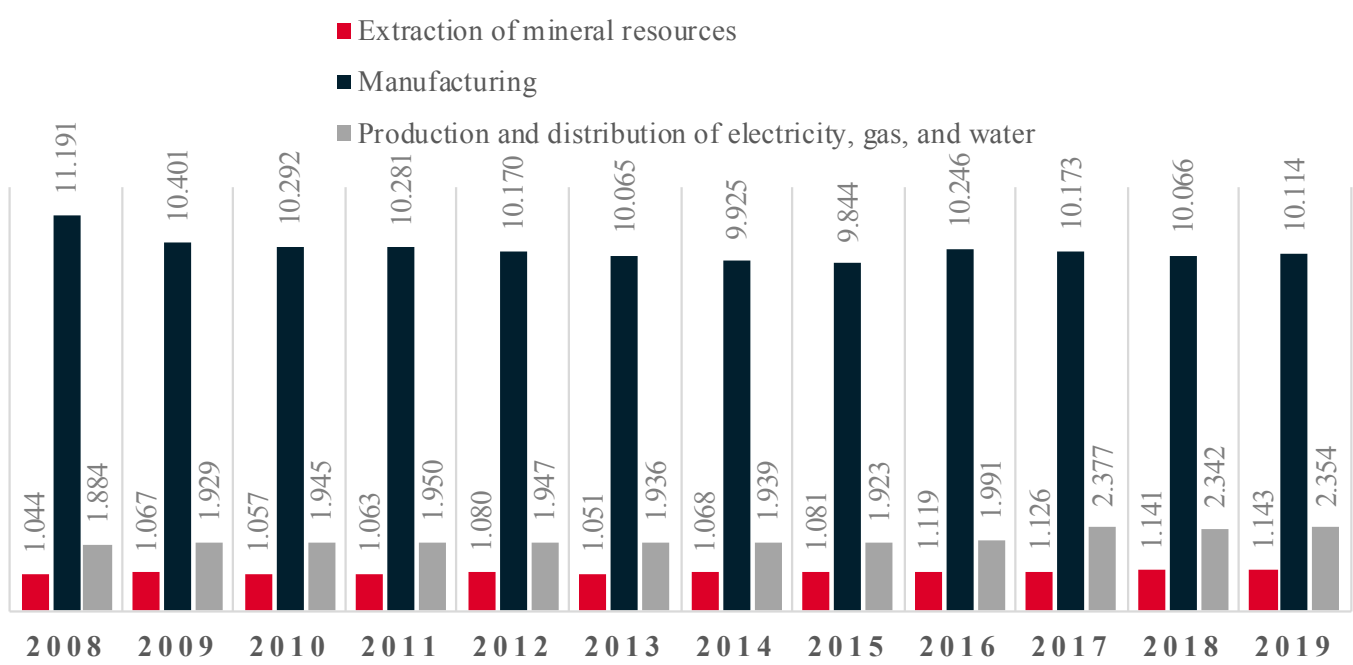

Figure 4: Dynamics of Russia's average annual number of employed persons across the sectors of industry, thousand people 


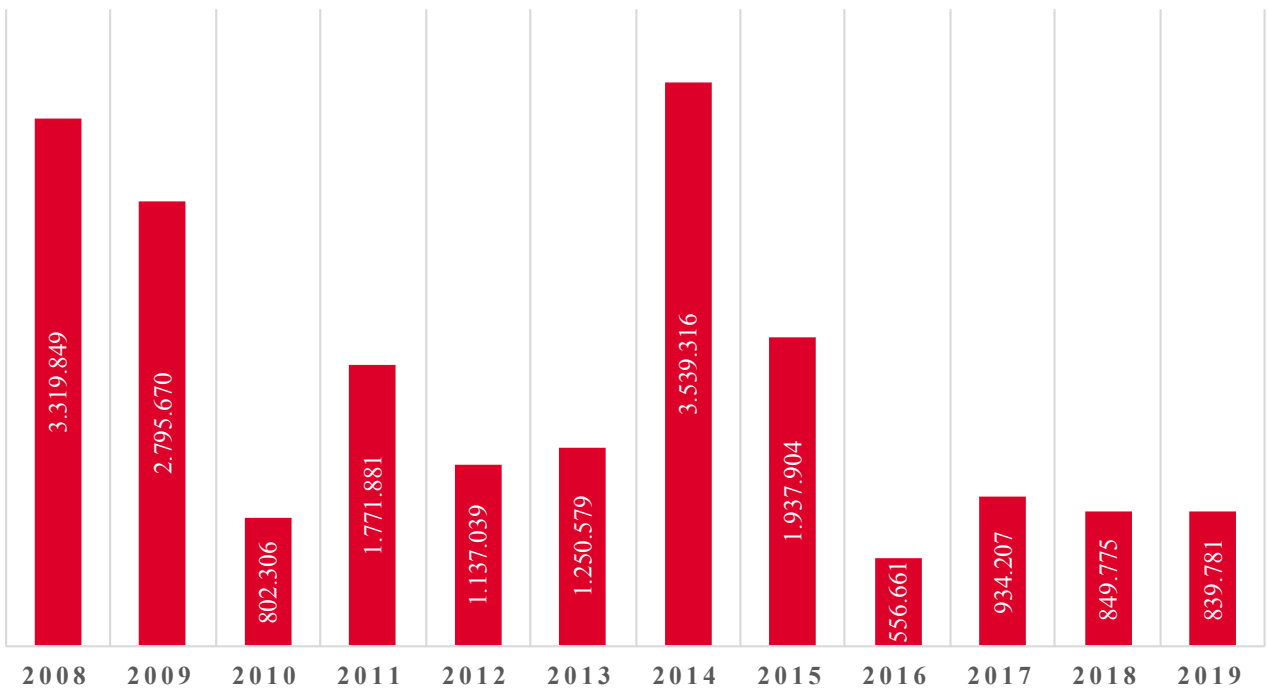

Figure 5: Russia's dynamics of capital outflow, million rubles

The decline in employment in the manufacturing sector is associated, among other things, with an increase in labor productivity thanks to production automation. Low pay ( $94 \%$ relative to the average pay across the economy), increased wear on equipment (over $46 \%$ ), and difficulties with workforce training are the key causes behind the decline in the number of persons employed in the sector (Foster-McGregor N, 2016).

The effect of change in global oil prices on the development of industrial production in the Extraction of Mineral Resources category is unquestionable. Every time there is a sharp drop in WTI and Brent oil prices, there also occurs a dip in the price of Russian crude Urals. This factor has special implications for the Russian economy, which operates based on the resource model of development. When global oil prices drop, industrial production in this sector shrinks and output declines in value terms.

A net capital outflow occurs when more money is taken out of the country by the private sector than is brought into the national economy from overseas (Matsuyama, K., 2009). Conversely, when more money comes into than is taken out of the country, the nation posts a net capital inflow (Pieper, U., 2003). Over the last few years, Russia has posted a net capital outflow, i.e. more money leaves the country than comes into it. This has been pronouncedly the case with the nation's extractive sector, as it accounts for a large share of Russia's exports, with revenue from the sale of its products being in foreign currency. Companies within the sector often fail to find a lucrative use for their funds, so many take them out of the country with a view to investing them in securities or investment projects in other countries. The decline in the values of this indicator is testimony that entrepreneurs are ready to invest in projects in Russia. In particular, such projects can be aimed at upgrading plant and equipment and modernizing and expanding production. The implementation of the above measures has helped drive the development of Russian industry and boost its output. Figure 5 illustrates the dynamics of capital outflow in Russia.

An analysis of the dynamics of net capital outflow from Russia indicates that the highest figures on this were posted in 2008 and in 2014. These specific years witnessed a number of substantial shocks, when the financial markets were in disarray and panic-stricken people rushed to buy foreign currency in hopes of protecting their hard-earned savings from depreciation. In the last 20 years, the nation posted a net capital inflow in 2006 and in 2007. In those years, the nation's GDP rose steadily, its financial reserves grew, and the standard of living of its population improved.

Currently, the primary source of technogenic impact on the environment in Russia is industrial production. Research by Rosstat suggests there is a relationship between increased output, increased demand for electricity, gas, and water, and increased emissions to the atmosphere. Figure 6 illustrates the dynamics of emissions in Russia.

The decline in emissions in Russia is associated with the conduct of special activities on minimizing emissions to

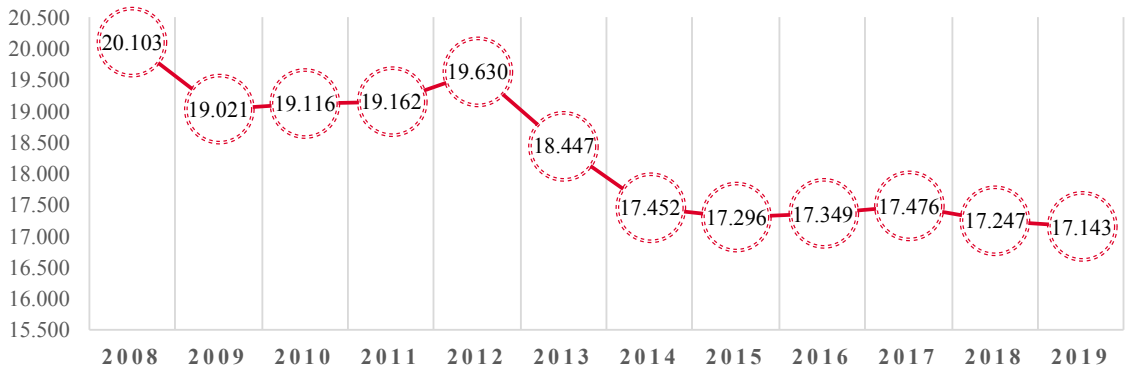

Figure 6: Russia's dynamics of emissions, thousand tons 


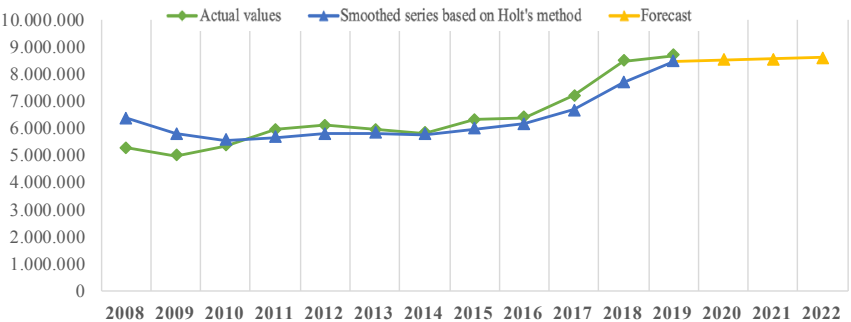

Figure 7: Initial, smoothed, and projected values of the Extraction of Mineral Resources series

(based on Holt's method).

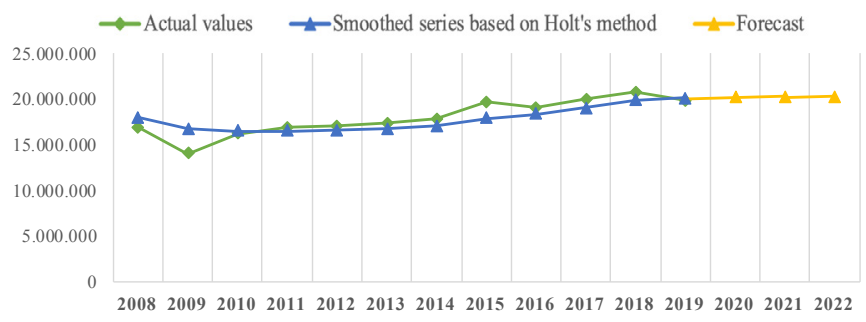

Figure 8. Initial, smoothed, and projected values of the Manufacturing series (based on Holt's method)

the atmosphere. This includes the use of "clean" fuel and progressive technology in production, minimization of fugitive emissions, improvement of the way such emissions are diffused, and the use of planning and development practices focused on the rational use of mountain ranges and forests as a shield between residential areas and industrial enterprises.

Combining the above macroeconomic indicators into a single system helped generate a forecast for and produce an analysis of structural change in Russia's industrial sector.

For the Extraction of Mineral Resources type of economic activity, the projected values for 2020 are 8,506,367.31, for 2021-8,553,872.10, and for 2022-8,601,376.88 million rubles. One is to expect a drop of $1.83 \%$ in output in 2020 compared with the previous year. The indicator is projected to rise gradually afterwards, with its values expected to match the 2019 level in 2022 (Figure 7).

For the Manufacturing type of economic activity, the projected values for 2020 are 20,231,963.34, for 2021$20,282,917.11$, and for 2022-20,333,870.87 million rubles. One is to expect a slight increase, one of $1.87 \%$, in output in 2020 compared with 2019 . The figure is projected to rise $0.25 \%$ in the period 2021-2022 (Figure 8).

For the Production and Distribution of Electricity, Gas, and Water type of economic activity, the projected values for 2020 are 3,099,334.76, for 2021 - 3,103,335.60, and for $2022-3,107,336.44$ million rubles. One is to expect a slight increase, one of $1.28 \%$, in output compared with 2019. The figure is projected to rise $0.13 \%$ in the period 2021-2022 (Figure 9).

Based on the results from constructing the factor model, the greatest effect on output in the extraction of mineral resources sector is from average annual number of employed persons in the sector and oil prices. These factors

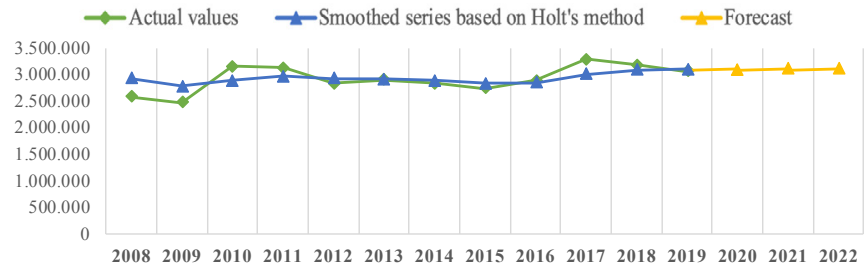

Figure 9: Initial, smoothed, and projected values of the Production and Distribution of Electricity, Gas, and Water series (based on Holt's method)

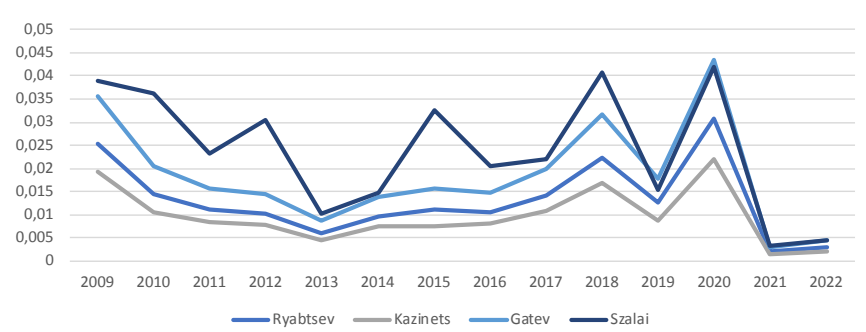

Figure 10: Forecast of structural changes in the industrial sector of the Russian economy based on the factor method

are followed by export growth rate, investment in fixed assets, and capital outflow. The greatest effect on output in the manufacturing sector is from invention activity coefficient and export growth rate. These factors are followed by average annual number of employed persons in the sector, share of workers with a higher education, and investment in fixed assets.

The greatest effect on output in the production and distribution of electricity, gas, and water sector is from export growth rate and average annual number of employed persons in the sector, followed by population size, demand for electricity, and investment in fixed assets.

Pronounced structural changes were also suggested by a forecast generated based on the factor method. Figure 10 illustrates Russia's structural shifts in the period 2008-2019 and projected structural shifts for the period 2020-2022, based on the use of the factor method.

Results and comparison of forecast values of industrial production volumes are in table 1.

Sharp changes in the macroeconomics, such as pandemics and crises, can be noted as limitations of the use of such forecasting methods.

\section{CONCLUSION}

In the period 2008-2019, peak values for Russia's structural shifts were registered in the following years:

- 2009: global economic crisis; negative dynamics of global GDP; record declines in global trade (over $10 \%$ ); increased unemployment;

- 2012: slowdown of the global economy; European economy entering a recession, whilst the Russian economy posted a steady performance. In 2012, Russia witnessed the launch of over 400 new production operations. The bulk of these production operations was accounted for by enterprises within the 
Table 1: Comparison of forecast values of industrial production volumes

\begin{tabular}{|c|c|c|c|c|}
\hline \multirow{3}{*}{ Method } & \multicolumn{4}{|c|}{ Year } \\
\hline & \multirow{2}{*}{$\begin{array}{c}\text { Actual data } \\
2019\end{array}$} & \multicolumn{3}{|c|}{ Forecast } \\
\hline & & 2020 & 2021 & 2022 \\
\hline \multicolumn{5}{|c|}{ Mining operation } \\
\hline Least squares method & \multirow{3}{*}{7902574,98} & 8975026,30 & 9136576,80 & 9282761,90 \\
\hline Holt's method & & 8506367,31 & 8553872,10 & 8601376,88 \\
\hline Factor analysis & & 7522868,29 & 7780720,05 & 8025068,30 \\
\hline \multicolumn{5}{|c|}{ Manufacturing industries } \\
\hline Least squares method & \multirow{3}{*}{20251050,24} & 21683123,20 & 22355300,00 & 23137735,50 \\
\hline Holt's method & & 20231963,34 & 20282917,11 & 20333870,87 \\
\hline Factor analysis & & 20438679,13 & 20878145,30 & 21153088,12 \\
\hline \multicolumn{5}{|c|}{ Production and distribution of electricity, gas and water } \\
\hline Least squares method & \multirow{3}{*}{3070573,33} & 3266046,30 & 3324835,10 & 3392994,30 \\
\hline Holt's method & & 3099334,76 & 3103335,60 & 3107336,44 \\
\hline Factor analysis & & 3191649,94 & 3249025,83 & 3282276,55 \\
\hline
\end{tabular}

food industry (dairy plants, meat-and-dairy farms, meat and fish processing, and canneries), enterprises within the construction industry (cement plants, prefab housing construction, and manufacture of tile, slabs, windows, and plumbing equipment), and various enterprises within the extractive, metallurgical, and automotive industries. The year also witnessed the emergence of a few dozen high-tech undertakings related to IT, telecommunications, and instrumentation:

- 2015: Russia dealing with the effects of a wave of sanctions imposed by Western governments; development of an import substitution program;

- 2018: VAT rate increasing to $20 \%$; launch of the Nord Stream 2 program; several periods of intense growth in gasoline prices, which led to increased prices for goods and services across a broad spectrum of categories; improved financial performance of producers and sellers of oil products.

Major structural changes have been projected to take place in 2020 in light of the outbreak of the COVID-19 pandemic and based on a number of factors associated with it, namely:

- $\quad$ sharp decline in WTI, Brent and Urals oil prices;

- closure of the borders and introduction of trade restrictions;

- decline in global GDP;

- increase in number of loss-making enterprises;

- increase in unemployment.

Some structural changes are expected due to a decline in output in the Extraction of Mineral Resources category. The figure is projected to exhibit a trend of increase in the years 2021 and 2022 and gradually match the level of 2019.

The Manufacturing and Production and Distribution of Electricity, Gas, and Water categories are projected to post growth throughout the forecast period. In the manufacturing sector, growth should be achieved thanks, among other things, to the development of new drugs for treating COVID-19, increased manufacture of related equipment, including artificial lung ventilation units, and increased demand for materials used for medical purposes. This demand is expected to be met thanks to the latest measures that are being taken to prevent the spread of the COVID-19 pandemic. Currently, many factories in Russia are retooling to manufacture medical masks, disinfectants, and protective gear for medical personnel.

Greater output in the production and distribution of electricity, gas, and water sector will be the result of rampedup activity by undertakings that are key contributors to the nation's GDP and increased exports.

The nation is not projected to witness significant changes in the structure of industrial production in 2021. No sharp swings in output across all the types of activity are expected. There are projections of an average increase of $2.5 \%$ in output. Minor structural changes are expected due to an increase in output in the Extraction of Mineral Resources category. This growth is expected to be based on stabilizing global oil prices, increasing exports, and a trend of decrease in capital outflow.

In 2022, changes in the structure of the nation's industrial production will be based on an emerging trend of increase in output in the extraction of mineral resources sector. The sector is expected to post an output increase of $3.1-3.3 \%$. With the Manufacturing and Production and Distribution of Electricity, Gas, and Water categories, the figure is projected to be not more than $1.5 \%$. On one hand, structural changes triggered by an increase in the share of output from resource-based undertakings in industry's total output should have a positive overall effect on the Russian economy. On the other hand, initiating progressive structural changes will require a thorough transformation of the structure of Russia's manufacturing industry. 


\section{ACKNOWLEDGEMENTS}

Project No. FSSW-2020-0009 "Development of a methodology for managing the competitiveness of enterprises in the field of commodity circulation in the digital economy" of the Ministry of Science and Higher Education of the Russian Federation.

\section{REFERENCES}

1. Abbas, S. A. 2018. Entrepreneurship and Information Technology Businesses in Economic Crisis, Entrepreneurship and Sustainability Issues 5(3):682692. https://doi.org/10.9770/jesi.2018.5.3(20)

2. Araujo, R. A., \& Lima, G. T. (2007). A structural economic dynamics approach to balance-of-payments-constrained growth. cambridge Journal of Economics, 31(5), 755-774.

3. Cadot O., Carrre C., Strauss-Kahn V. (2007). Export Diversification: What's Behind the Hump? / Centre for Economic Policy Research, Discussion Paper No 6590.

4. Chenery, H. B., \& Taylor, L. (1968). Development patterns: among countries and over time. The Review of Economics and Statistics, 391-416.

5. Clark, C. (1957). The Conditions of Economic Progress Macmillan \& Co. London, 108, 109.

6. Dasgupta, S. and Singh, A. (2006) Manufacturing, services and premature de-industrialisation in developing countries: a Kaldorian empirical analysis. ESRC Centre for Business Research, University of Cambridge.

7. De Vries, G., Timmer, M., \& de Vries, K. (2015). Structural transformation in Africa: Static gains, dynamic losses. The Journal of Development Studies, 51(6), 674-688.

8. Diao, X., McMillan, M. and Rodrik, D. (2017) The recent growth boom in developing economies: $A$ structural change perspective // National Bureau of Economic Research. No. w23132.

9. Di Meglio, G., Gallego, J., Maroto, A., \& Savona, M. (2015). Services in Developing Economies: A new chance for catching-up?// SPRU Working Paper Series, SWPS 2015-32 (November).

10. Dondur, N., Pokrajac, S., Spasojević-Brkić, V., \& Grbić, S.(2011). Decomposition of productivity and allocative efficiency in Serbian industry. FME Transactions, 39 (2), 73-78.

11. Federal State Statistic Service https://www.gks.ru

12. Fisher, A.G.B. (1939) Production, primary, secondary and tertiary//The Economic Record 15: 24-38.
13. Foster-McGregor N., Verspagen B. (2016) The Role of Structural Change in the Economic Development of Asian Economies// Asian Development Review, vol. 33, no. 2, pp. 74-93.

14. Harberger, A. C. (1998). A vision of the growth process. The American Economic Review, 88(1), 1-32.

15. Hausmann R., Hidalgo C.A. (2011) The network structure of economic output //Journal of Economic Growth.16:309-342.

16. Imbs, J., Montenegro C., Wacziarg R. (2014) Economic Integration and Structural Change//Mimeo. June 2014.

17. Humbatova, S.I., Tanriverdiev, S.M., Mammadov,I.N., Hajiyev, N. G.-O.2020. Impact of investment on GDPand non-oil GDPin Azerbaijan. Entrepreneurship and Sustainability Issues, 7(4),2645-2663. http://doi.org/10.9770/jesi.2020.7.4(6)

18. Kays, H. E., Karim, A. M., \& Daud, M. R. C. (2020). A responsive multiplicative Holt-Winters approach for enhanced forecasting accuracy. International Journal of Industrial and Systems Engineering, 35(1), 114-134.

19. Koren, M. and Tenreyro, S. (2003) Diversification and development. FRB of Boston Working Paper. No. 3-3.

20. Kruger J.J. (2008) Productivity and Structural Change: a Review of the Literature //Journal of Economic Surveys.Vol. 22. No. 2. pp. 330-363.

21. Kuznets, S. (1973) Modern economic growth: findings and reflections. American Economic Review 63: 247-258.

22. Lewis, W. A. (1954). Economic development with unlimited supplies of labour. The manchester school, 22(2), 139-191.

23. Lin, J. Y. and Rosenblatt D. (2012). Shifting Patterns of Economic Growth and IRethinking Development.// Journal of Economic Policy Reform 15 (3): 171-194.

24. Matsuyama, K. (2009) Structural Change in an Interdependent World: A Global View of Manufacturing Decline //Journal of the European Economic Association, Vol. 7, No. $2 / 3$.

25. Maslikhina, V. (2017). Spatial concentration of the manufacturing industry: Evidence from Russia. Journal of Applied Engineering Science, 15(4), 509-517.

26. McMillan, M., Rodrik, D. and Sepulveda, C. (2017) Structural change, fundamentals and growth: a framework and case studies // National Bureau of Economic Research. No. w23378. 
27. McMillan, M., Rodrik, D., \& Verduzco-Gallo, Í. (2014). Globalization, structural change, and productivity growth, with an update on Africa. World Development, 63, 11-32.

28. Meckl, J. (2002). Structural change and generalized balanced growth. Journal of Economics, 77(3), 241266.

29. Pieper, U. (2003). Sectoral regularities of productivity growth in developing countries-a Kaldorian interpretation. Cambridge Journal of Economics, 27(6), 831-850.

30. Rodrik, D. (2003) Growth Strategies. Cambridge, MA: Kennedy School of Government, Harvard University.

31. Rodrik, D. (2013) Structural change, fundamentals and growth: an overview. Institute for Advanced Study. September.

32. Silva, E.G., Teixeira, Aurora A.C. (2008) Surveying structural change: Seminal contributions and a bibliometric account// Structural Change and Economic Dynamics. Vol.19. pp.273-300.

33. Romano, L., \& Trau, F. (2017). The nature of industrial development and the speed of structural change. Structural Change and Economic Dynamics.

34. Szirmai, A. (2012) Industrialisation as an engine of growth in developing countries, 1950-2005. Structural Change and Economic Dynamics, 23(4), pp. 406-420.
35. Thirlwall, A.P. (2013). Economic Growth in an Open Developing Economy: The Role of Structure and Demand, Edward Elgar, Cheltenham.

36. Timmer, M.P. and de Vries, G.J. (2009) Structural change and growth accelerations in Asia and Latin America: a new sectoral data set. Cliometrica, 3(2), pp.165-190.

37. UNIDO (2016) United Nations Industrial Development Organization, Industrial Development Report. The Role of Technology and Innovation in Inclusive and Sustainable Industrial Development. Vienna: UNIDO.

38. Vu, K.M. (2017) Structural change and economic growth: Empirical evidence and policy insights from Asian economies// Structural Change and Economic Dynamics. 41. 64-77. W P 12 - 21. The Asian Development Bank (ADB).

39. Wells, H., \& Thirlwall, A. P. (2003). Testing Kaldor's growth laws across the countries of Africa. African development review, 15(2-3), 89-105.

40. Xiong, Tao, Chongguang Li, and Yukun Bao. "Interval-valued time series forecasting using a novel hybrid Holtl and MSVR model." Economic Modelling 60 (2017): 11-23. 